\title{
Transarterial chemoembolization (TACE) combined with sorafenib versus TACE for hepatocellular carcinoma with portal vein tumor thrombus: a systematic review and meta-analysis
}

\author{
XiuPing Zhang ${ }^{1, *}$, Kang Wang ${ }^{1,}{ }^{*}$, Meng Wang ${ }^{2,}{ }^{*}$, Guang Yang ${ }^{3}$, XiaoFei Ye ${ }^{2}$, MengChao \\ $\mathbf{W u}^{1}$ and ShuQun Cheng ${ }^{1}$ \\ ${ }^{1}$ Department of Hepatic Surgery VI, Eastern Hepatobiliary Surgery Hospital, Second Military Medical University, Shanghai, \\ China \\ 2 Department of Medical Statistical, Second Military Medical University, Shanghai, China \\ ${ }^{3}$ Company 5 of Student Brigade, Second Military Medical University, Shanghai, China \\ * These authors have contributed equally to this work \\ Correspondence to: ShuQun Cheng, email: chengshuqun@aliyun.com \\ Keywords: hepatocellular carcinoma, PVTT, TACE, sorafenib, combined treatment \\ Received: November 08, $2016 \quad$ Accepted: January 09, $2017 \quad$ Published: February 03, 2017
}

Copyright: Zhang et al. This is an open-access article distributed under the terms of the Creative Commons Attribution License (CC-BY), which permits unrestricted use, distribution, and reproduction in any medium, provided the original author and source are credited.

\section{ABSTRACT}

Background. The benefits of transarterial chemoembolization plus sorafenib (TACE-S) in hepatocellular carcinoma (HCC) with portal vein tumor thrombus (PVTT) remain controversial. We compared the effectiveness and safety of TACE-S and TACE for HCC with PVTT.

Methods. The Cochrane Library, PubMed, EMBASE, Chinese National Knowledge Infrastructure, VIP, Wan Fang, and Sino Med databases were systematically searched for studies of HCC with PVTT treated using TACE-S. Two authors independently extracted study outcomes, including overall survival (OS), time to progression (TTP), objective response (tumor response) and adverse events (AEs).

Results. Eight high-quality, retrospective studies with 1091 patients (TACE-S $=356$, TACE $=735$ ) were included in the review. Five retrospective studies with 973 patients (TACE-S $=238$, TACE $=735$ ) were included in the meta-analysis. The objective response rate (ORR, $O R=3.59,95 \% \mathrm{CI}=1.74-7.39 ; \mathrm{I}^{2}=21 \%, P=0.0005$ ) and disease control rate $\left(D C R, O R=4.72,95 \% C I=1.75-12.72 ; I^{2}=56 \%, P=0.002\right)$ favored TACE-S. TACE-S significantly increased 6 -month OS $(\mathrm{OR}=3.47 ; 95 \% \mathrm{CI}=2.47-4.89$; $\left.I^{2}=0 \%, P<0.00001\right)$ and 1 -year OS (OR=3.10; 95\% CI=2.22-4.33; $I^{2}=41 \%, P<$ $0.00001)$. The hazard ratio (HR) for OS (HR=0.62; $95 \% \mathrm{CI}=0.51-0.75 ; \mathrm{I}^{2}=30 \%, P$ $<\mathbf{0 . 0 0 0 0 1 )}$ also indicated that TACE-S was superior to TACE. TACE-S with PVTT had better outcomes in the first-order portal vein branch and lower-order portal vein branches than in the main portal vein and upper branches to superior mesenteric vein. The most common AEs were hand-foot skin reaction (HFSR, 178; 73\%), diarrhea $(142 ; 58 \%)$ and alopecia $(76 ; 31 \%)$; AEs of grade $3 / 4$ were rare.

Conclusions. TACE-S may improve OS, ORR, TTP and DCR for HCC patients with PVTT compared to TACE.

\section{INTRODUCTION}

Hepatocellular carcinoma (HCC) is the most common cancer and has dismal outcomes [1,2]. Portal vein tumor thrombosis (PVTT) is the most commonly recognized risk factor for prognosis. PVTT occurs in 44$62.2 \%$ of patients with advanced $\mathrm{HCC}$ and is associated with a natural median survival time (MST) of 2.7-4 months $[3,4]$. Despite recent advances in the treatment of such patients, the treatment strategies for patients with HCC with PVTT remain controversial. 
Table 1: Patient characteristics

\begin{tabular}{|c|c|c|c|c|c|c|c|c|c|c|c|c|c|c|}
\hline Study (year) & $\begin{array}{l}\text { Study } \\
\text { design }\end{array}$ & Treatment & Country & Patients & $\begin{array}{l}\text { Type } \\
\text { of } \\
\text { PVTT(III/ } \\
\text { II/I) }\end{array}$ & $\begin{array}{l}\begin{array}{l}\text { Tumor } \\
\text { size }(\mathrm{cm}) \\
(<5 / 5-\end{array} \\
10 />10)\end{array}$ & AGE & $\operatorname{Sex}(\mathbf{M} / \mathbf{F})$ & $\begin{array}{l}\text { Child- } \\
\text { Pugh } \\
\text { (A/B/C) }\end{array}$ & $\begin{array}{l}\text { ECOG } \\
\operatorname{Ps}(0 / 1 / 2)\end{array}$ & $\begin{array}{l}\text { Virology } \\
\text { HBV/ } \\
\text { HCV/ } \\
\text { Other }\end{array}$ & $\begin{array}{ll}\text { Total } & \text { bilirubin } \\
\text { level } & (\mu \mathrm{mol} / \mathrm{L})\end{array}$ & $\begin{array}{l}\text { Serum } \\
\text { albumin level } \\
(\mathrm{g} / \mathrm{L})\end{array}$ & $\begin{array}{l}\text { AFP(mg/L) } \\
(\leqq 400 / \\
>\mathbf{4 0 0})\end{array}$ \\
\hline \multirow[t]{2}{*}{ Нао 2015} & $\mathrm{R}$ & $\mathrm{T}+\mathrm{S}$ & China & 32 & $10 / 14 / 8^{a}$ & NA & $45.6 \pm 12.1$ & $29 / 3$ & NA & $\begin{array}{l}14 / 18- \\
(0 / 1-2)\end{array}$ & NA & NA & NA & $13 / 19$ \\
\hline & & $\mathrm{T}$ & & 38 & $11 / 21 / 6^{\mathrm{a}}$ & NA & $48.3 \pm 9.8$ & $34 / 4$ & NA & $\begin{array}{l}15 / 23- \\
(0 / 1-2)^{\mathrm{c}}\end{array}$ & NA & NA & NA & $15 / 23$ \\
\hline \multirow[t]{2}{*}{ Chen 2014} & $\mathrm{R}$ & $\mathrm{T}+\mathrm{S}$ & China & 21 & $10 / 7 / 4$ & $6 / 10 / 5$ & $57 \pm 14$ & $17 / 4$ & $20 / 1 / 0$ & $4 / 12 / 5$ & NA & NA & NA & NA \\
\hline & & $\mathrm{T}$ & & 23 & $7 / 13 / 3$ & $5 / 9 / 9$ & $50 \pm 12$ & $19 / 4$ & $20 / 3 / 0$ & $4 / 11 / 8$ & NA & NA & NA & NA \\
\hline \multirow[t]{2}{*}{ Luo 2014} & $\mathrm{R}$ & $\mathrm{T}+\mathrm{S}$ & China & 26 & $21 / 15 / 15^{\mathrm{b}}$ & NA & $45.78 \pm 11.3$ & $30 / 21$ & ${ }_{\mathrm{b}}^{13 / 19 / 19}$ & NA & NA & NA & NA & NA \\
\hline & & $\mathrm{T}$ & & 25 & & NA & & & & NA & NA & NA & NA & NA \\
\hline \multirow[t]{2}{*}{ Zhu 2014} & $\mathrm{R}$ & $\mathrm{T}+\mathrm{S}$ & China & 46 & $10 / 19 / 17$ & NA & $48.46 \pm 8.1$ & $39 / 7$ & $39 / 7 / 0$ & $\begin{array}{l}22 / 24- \\
(0 / 1-2)^{\mathrm{c}}\end{array}$ & $38 / 5 / 3$ & $32.1 \pm 9.7$ & $34.6 \pm 4.5$ & $23 / 23$ \\
\hline & & $\mathrm{T}$ & & 45 & $11 / 21 / 13$ & NA & $51.96 \pm 12.2$ & $38 / 7$ & $39 / 6 / 0$ & $\begin{array}{l}20 / 25- \\
(0 / 1-2)^{\mathrm{c}}\end{array}$ & $40 / 1 / 4$ & $33.8 \pm 11.2$ & $35.2 \pm 4.3$ & $19 / 26$ \\
\hline Zhang 2015 & $\mathrm{R}$ & $\mathrm{T}+\mathrm{S}$ & China & 45 & NA & NA & $50.1 \pm 8.8$ & $43 / 2$ & $21 / 13 / 11$ & $0 / 41 / 4$ & $44 / 1 / 0$ & $36.8 \pm 5.7$ & $20.4 \pm 6.8$ & $3 / 42$ \\
\hline Pan 2014 & $\mathrm{R}$ & $\mathrm{T}+\mathrm{S}$ & China & 41 & $33 / 8 / 0^{a}$ & $0 / 25 / 16$ & 52(range:29-73) & $38 / 3$ & $35 / 6 / 0$ & $20 / 21 / 0$ & $40 / 1 / 0$ & $26 / 15(\leqq 2 />2)$ & $5 / 36(<35 />35)$ & $22 / 19$ \\
\hline $\begin{array}{l}\text { Chen } \\
2013\end{array}$ & $R$ & $\mathrm{~T}+\mathrm{S}$ & China & 32 & $10 / 10 / 12$ & NA & 44 & $29 / 3$ & $22 / 10 / 0$ & $2 / 28 / 2$ & $32 / 0 / 0$ & NA & NA & $4 / 18$ \\
\hline \multirow[t]{2}{*}{ Wang 2016} & $\mathrm{R}$ & $\mathrm{T}+\mathrm{S}$ & China & 113 & $37 / 45 / 31$ & $29 / 84 / 0$ & $58 / 55(\leqq 50 />50)$ & $77 / 36$ & $110 / 3 / 0$ & NA & $29 / 0 / 0$ & $\begin{array}{l}49 / 64(\leqq 18.8 / \\
>18.8) \mathrm{mmol} / \mathrm{L}\end{array}$ & $\begin{array}{l}39 / 74(\leqq 34 / \\
>34)\end{array}$ & $45 / 68$ \\
\hline & & $\mathrm{T}$ & & 604 & $269 / 288 / 47$ & $0 / 25 / 16$ & $285 / 319$ & $534 / 70$ & $567 / 37 / 0$ & NA & $125 / 0 / 0$ & $353 / 251$ & $130 / 474$ & $230 / 374$ \\
\hline
\end{tabular}

Note: R: Retrospective study, NA: Not applicable, TACE: Transarterial chemoembolization, S: sorafenib, OG PS: eastern Cooperative Oncology Group Performance Status, Type A: Main portal vein, Type B: First-order portal vein branch, Type C: Second- or lower-order portal vein branches. AFP: alpha fetoprotein

a: The type of PVTT in study Hao2015 and Pan2014 was performed by Cheng's classification [28]. The data of PVTT type in Cheng's classification were that 1/2/3/4 Hao2015 T+S: 8/14/7/3, T: 6/21/7/4, Pan2014 0/8/23/10. We change type I by Cheng's classification to type C, type II by Cheng's classification to type B, type III by Cheng's classification to type A.

b: The both patient accepted combine treat and TACE alone are 21/15/15.

c: The study record both level1 plus level 2 number.

According to the Barcelona Clinic Liver Cancer (BCLC) treatment strate gy, sorafenib is the only recommended treatment for patients with $\mathrm{HCC}$ with PVTT. However, recent studies have shown that TACE can be safely performed even in HCC patients with PVTT if they have good liver function and sufficient collateral circulation after portal vein occlusion $[5,6]$. Some recent studies have suggested that TACE might benefit PVTT, but its effect was limited [7-9]. TACE-S appears to be a promising method for HCC patients with PVTT. Several retrospective and prospective studies of this therapy have summarized the efficacy and safety for PVTT patients [10, 11]. Moreover, some meta-analyses of this new treatment for unresectable HCC without PVTT have optimized this treatment modality [12-15]. However, additional randomized, controlled studies (RCTs) of TACE-S for HCC with PVTT are needed to confirm the efficacy and safety of this method.

Although this combination therapy has been used in patients suffering from HCC with PVTT, the current data on therapeutic effects are controversial, and its clinical role has not been decided. Here, we performed the first systematic review and meta-analysis of clinical trials to assess the efficacy and safety of TACE-S and TACE therapy alone for HCC patients with PVTT.

\section{RESULTS}

\section{Patient characteristics}

The search strategy identified 1279 relevant studies, of which 1069 were duplicates. A total of 203 references were excluded after the titles and abstracts were screened; then, 9 studies were excluded for other reasons, as shown in Figure 1. Finally, 8 retrospective, controlled studies $[7,10,20-25]$ were eligible for inclusion and qualitative synthesis, and 5 studies were included in the metaanalysis (Figure 1A). This systematic review included a total of 8 retrospective studies. Table 1 presents the basic characteristics of the included studies. A total of 1091 patients with HCC and PVTT were included, of which 356 received TACE-S therapy and 735 received TACE alone. More men than women with HCC and PVTT were included in the analysis. The tumor size mostly centralized on $5-10 \mathrm{~cm}$. The age of patients ranged from 


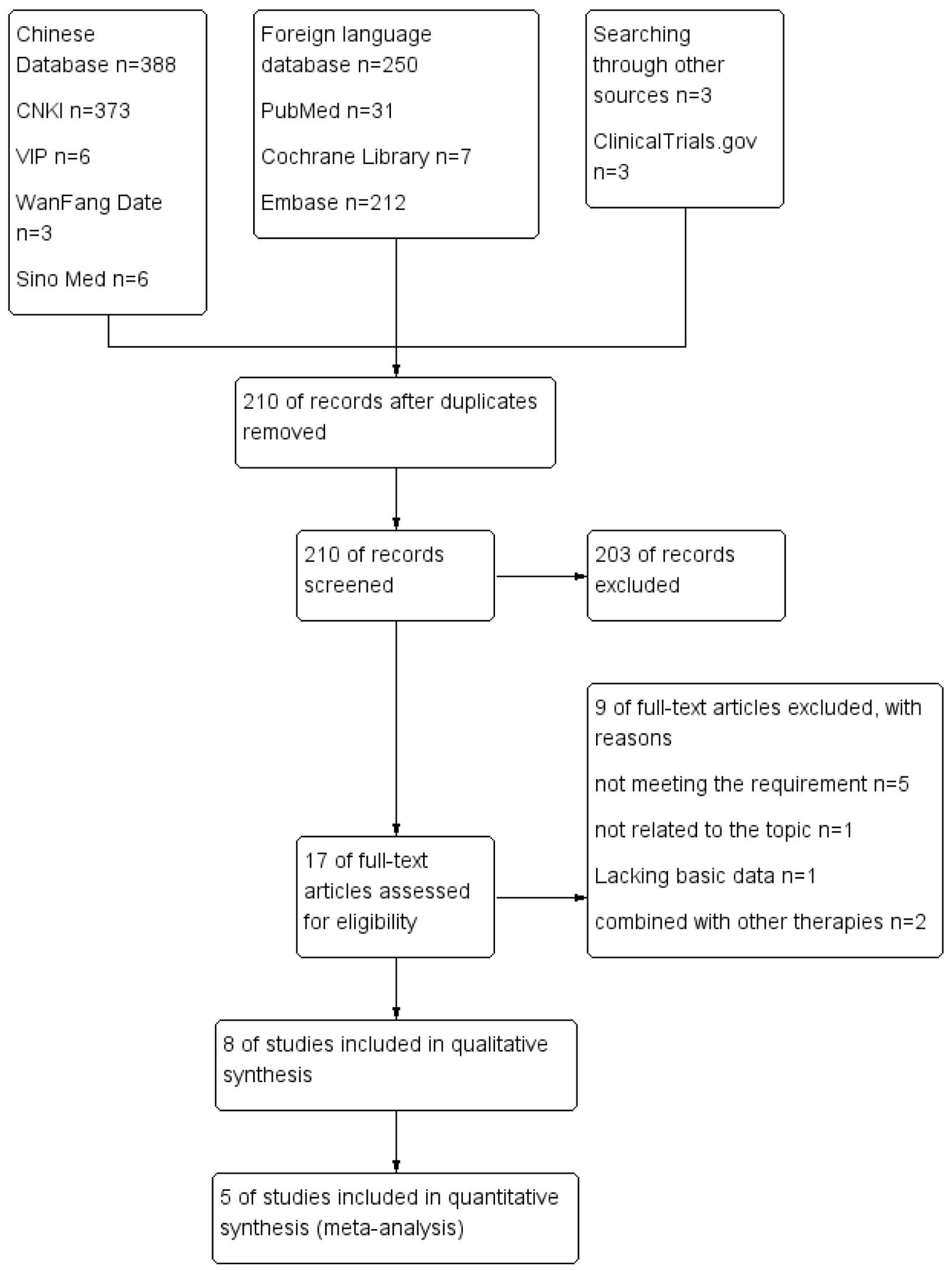

Figure 1: PRISMA flow diagram of the process for the identification of eligible studies. CNKI: Chinese National Knowledge Infrastructure; VIP: Chongqing VIP database for Chinese Technical Periodicals; Wan Fang: Wan Fang Database; Sino Med: Chinese Biological Medical Literature Database. 
Table 2: Procedures of TACE and sorafenib combination therapy.

\begin{tabular}{|c|c|c|c|c|}
\hline Study & TACE & & & Sorafenib \\
\hline & Duration and interval & Chemotherapeutic agents & Embolic agents & \\
\hline Hao 2015 & $\begin{array}{l}\text { Mean 2.4times } \\
\text { (range: } 1-5 \text { ) } \\
\text { 4-8 week interval } \\
\end{array}$ & $\begin{array}{l}\text { pirarubicin } 30 \sim 60 \mathrm{mg} \\
\text { oxaliplatin } 100 \sim 150 \mathrm{mg}\end{array}$ & lipiodol 5 15ml & $\begin{array}{l}400 \mathrm{mg} \text { bid at } 3-7 \text { days after the first } \\
\text { TACE session, no breaks before or } \\
\text { after repeated TACE }\end{array}$ \\
\hline Chen 2014 & $2.5 \pm 1.1$ times & $\begin{array}{l}\text { epirubicin, } \\
\text { platinum agent, camptothecin }\end{array}$ & $\begin{array}{l}\text { lipiodol, absorbable gelatin sponge and } \\
\text { polyvinyl alcohol }\end{array}$ & $\begin{array}{l}400 \mathrm{mg} \text { bid at } 7 \text { days before the first } \\
\text { TACE session and } 14 \text { days after it }\end{array}$ \\
\hline Luo 2014 & NA & $\begin{array}{l}\text { 10-40 mg pirarubicin } 40-80 \mathrm{mg} \\
\text { nedaplatin } 500-1000 \mathrm{mg} 5-\mathrm{FU}\end{array}$ & 10-40ml mixed lipiodol & $400 \mathrm{mg}$ bid \\
\hline Zhu 2014 & $\begin{array}{l}\text { Mean 3.6times } \\
\text { (range1-8) } \\
\text { 4-6 week interval }\end{array}$ & $\begin{array}{l}20-60 \mathrm{mg} \text { doxorubicin } \\
20-50 \mathrm{mg} \text { lobaplatin }\end{array}$ & $\begin{array}{l}2-20 \mathrm{~mL} \text { lipiodol } \\
300-1000-\mu \mathrm{m} \text { polyvinyl alcohol particles }\end{array}$ & $\begin{array}{l}400 \mathrm{mg} \text { bid at } 3-5 \text { days after the } \\
\text { first TACE session, no breaks } \\
\text { before or after repeated TACE }\end{array}$ \\
\hline Zhang 2015 & Mean 2.6 (range: $1-5$ ) & 20-40mg epirubicin & 10-20 mL lipiodol Gelfoam & $\begin{array}{l}400 \mathrm{mg} \text { bid after } 1-3 \text { days TACE, } \\
\text { and administration } \\
\text { was suspended on the day a } \\
\text { repeated TACE procedure was } \\
\text { performed }\end{array}$ \\
\hline Pan 2014 & NA & $\begin{array}{l}40-60 \mathrm{mg} \text { epirubicin } 6-10 \mathrm{mg} \\
\text { mitomycin C }\end{array}$ & $\begin{array}{l}8-30 \mathrm{ml} \text { lipiodol } \\
\text { gelatin sponge }\end{array}$ & $\begin{array}{l}400 \mathrm{mg} \text { bid after } 3 \text { days TACE } \\
\text { A } 3 \text {-day interruption in sorafenib } \\
\text { was adopted after each subsequent } \\
\text { TACE cycle. }\end{array}$ \\
\hline Chen JW 2013 & NA & $\begin{array}{l}50 \mathrm{mg} \text { lobaplatin } \\
30 \mathrm{mg} \text { THP } \\
1.0 \mathrm{~g} 5-\mathrm{FU} \\
\end{array}$ & $\begin{array}{l}\text { super liquefied iodized oil, gelatin } \\
\text { sponge and polyvinyl alcohol }\end{array}$ & $400 \mathrm{mg}$ bid after $3-7$ days TACE \\
\hline Wang 2016 & 6 to 8 weeks interval & $\begin{array}{l}20 \text { to } 60 \mathrm{mg} \text { doxorubicin } \\
\text { hydrochloride, } 5 \mathrm{mg} \text { cisplatin }\end{array}$ & $\begin{array}{l}5 \text { to } 30 \mathrm{ml} \text { lipiodol } \\
\text { Gelfoam fragments }\end{array}$ & $\begin{array}{l}400 \mathrm{mg} \text { bid } \\
\text { twice daily at } 1 \text { week after the first } \\
\text { TACE session }\end{array}$ \\
\hline
\end{tabular}

Table 3: Tumor responses in patients of included studies

\begin{tabular}{|c|c|c|c|c|c|c|c|c|c|}
\hline Study & $\begin{array}{l}\text { Type of } \\
\text { PVTT }\end{array}$ & Follow-up time & $\begin{array}{l}\text { Complete } \\
\text { response }\end{array}$ & $\begin{array}{l}\text { Partial } \\
\text { response }\end{array}$ & $\begin{array}{l}\text { Stable } \\
\text { disease }\end{array}$ & $\begin{array}{l}\text { Progressive } \\
\text { disease }\end{array}$ & Death & $\begin{array}{l}\text { Objective response } \\
\text { rate }(\%)\end{array}$ & $\begin{array}{l}\text { Disease control } \\
\text { rate }(\%)\end{array}$ \\
\hline \multirow[t]{2}{*}{ Hao 2015} & $\mathrm{~T}+\mathrm{S}$ & NA & 0 & 10 & 8 & 14 & 0 & 31.3 & 56.2 \\
\hline & $\mathrm{T}$ & NA & 0 & 4 & 6 & 28 & 0 & 10.5 & 26.3 \\
\hline \multirow[t]{2}{*}{ Chen 2014} & $\mathrm{~T}+\mathrm{S}$ & $\begin{array}{c}6 \text { months } \\
\text { 1year }\end{array}$ & $\begin{array}{l}0 \\
0 \\
\end{array}$ & $\begin{array}{l}0 \\
0 \\
\end{array}$ & $\begin{array}{c}10 \\
1 \\
\end{array}$ & $\begin{array}{l}6 \\
4 \\
\end{array}$ & $\begin{array}{c}5 \\
16 \\
\end{array}$ & $\begin{array}{l}0.0 \\
0.0 \\
\end{array}$ & $\begin{array}{c}47.6 \\
4.8 \\
\end{array}$ \\
\hline & $\mathrm{T}$ & $\begin{array}{c}6 \text { months } \\
\text { 1year }\end{array}$ & $\begin{array}{l}0 \\
0\end{array}$ & $\begin{array}{l}0 \\
0 \\
\end{array}$ & $\begin{array}{l}0 \\
0 \\
\end{array}$ & $\begin{array}{l}5 \\
0 \\
\end{array}$ & $\begin{array}{l}18 \\
23\end{array}$ & $\begin{array}{l}0.0 \\
0.0\end{array}$ & $\begin{array}{l}0.0 \\
0.0 \\
\end{array}$ \\
\hline \multirow[t]{2}{*}{ Luo 2014} & $\mathrm{~T}+\mathrm{S}$ & 9months & 0 & 12 & 8 & 6 & 0 & 46.2 & 76.9 \\
\hline & $\mathrm{T}$ & 9months & 0 & 8 & 9 & 8 & 0 & 32.0 & 68.0 \\
\hline \multirow[t]{2}{*}{ Zhu 2014} & $\mathrm{~T}+\mathrm{S}$ & NA & 0 & 13 & 13 & 20 & 0 & 28.3 & 57 \\
\hline & $\mathrm{T}$ & NA & 0 & 2 & 4 & 39 & 0 & 4.4 & 13 \\
\hline Zhang 2015 & $\mathrm{~T}+\mathrm{S}$ & 3months & 0 & 9 & 15 & 12 & 9 & 20.0 & 56 \\
\hline Pan 2014 & $\mathrm{~T}+\mathrm{S}$ & NA & 1 & 7 & 25 & 8 & 0 & 19.5 & 80.5 \\
\hline Chen JW 2013 & $\mathrm{~T}+\mathrm{S}$ & 2 months & 0 & 8 & 12 & 12 & 0 & 25.0 & 62.5 \\
\hline Wang 2016 & $\begin{array}{c}\mathrm{T}+\mathrm{S} \\
\mathrm{T}\end{array}$ & $\begin{array}{l}\text { NA } \\
\text { NA }\end{array}$ & $\begin{array}{l}\text { NA } \\
\text { NA }\end{array}$ & $\begin{array}{l}\text { NA } \\
\text { NA }\end{array}$ & $\begin{array}{l}\text { NA } \\
\text { NA }\end{array}$ & $\begin{array}{l}\text { NA } \\
\text { NA }\end{array}$ & $\begin{array}{l}\text { NA } \\
\text { NA }\end{array}$ & $\begin{array}{c}\text { NA } \\
\text { NA }\end{array}$ & $\begin{array}{l}\text { NA } \\
\text { NA }\end{array}$ \\
\hline
\end{tabular}

Note: All used RECIST, response evaluation in solid tumors.

The Meta analysis used Chen2014 6month data.

40 to 70 approximately. The baseline liver function of most of the participants was Child-Pugh A [10, 21, 2325]. There was no difference between TACE-S and TACE group in patients' liver function. The baseline ECOG of the included patients was reported in six studies, and the proportion of patients without considerable ECOG varied among the studies. The serum AFP level of these patients was more than $400 \mathrm{mg} / \mathrm{L}$ according to six studies. Five studies reported virology, and most of the participants had HBV. The baseline characteristics of the patients in the studies were recorded (Table 1).

\section{Treatment regimens}

The number of treatment cycles of TACE ranged from 1 to 8 times, and the mean number ranged from 2.4 to 3.6. The chemotherapeutic agents differed among the included studies. However, the embolic agents were same, such as lipiodol, gelatin sponge and Gelfoam The daily dosage of sorafenib was $400 \mathrm{mg}$ bid in all studies. In most of the included studies, the time of use of sorafenib ranged from 1 to 7 days after the first TACE session, with no breaks before or after repeated TACE if adverse events 
of grade 3/4 did not occur. None of the patients received other treatments (Table 2).

\section{Tumor response}

The seven of the included eight studies reported response assessment by RECIST (Response Evaluation Criteria in Solid Tumors), and the outcomes are shown in Table 3. The tumor response to treatment was classified as complete response (CR), partial response (PR), stable disease (SD), and progression of disease (PD). The DCR (DCR defined as $\mathrm{CR}+\mathrm{PR}+\mathrm{SD}$ ) was reported in 7 studies and ranged from $4.8 \%$ to $80.5 \%$ in the combination group and $0 \%$ to $68.0 \%$ in the TACE-alone group. The ORR (ORR defined as CR + PR) ranged from $0 \%$ to $46.2 \%$ in the combination group and $0 \%$ to $32.0 \%$ in the TACEalone group. Because the follow-up time ranged from 2 months to 1 year, the results obviously varied. In addition, some studies did not list follow-up time, although it was reported by Hao [20], Zhu et al. [23]. and Pan et al. [24]. The DCR of the combination treatment was superior to that of TACE alone in the studies reported by Hao [20], Chen et al. [21], Luo LZ and Luo D [22] and Zhu et al. [23]. The DCR of combination treatment in all seven studies ranged from $4.8 \%$ to $80.5 \%$, and the majority of DCRs were higher than $50 \%$.

Four studies [20-23] indicated that the DCR of combined treatment was superior to that of TACE alone. Meta-analysis of retrospective studies by ORR ( $\mathrm{OR}=3.59$, $95 \% \mathrm{CI}=1.74-7.39 ; \mathrm{I} 2=21 \%, \mathrm{P}=0.0005$; Figure $2 \mathrm{~A}$ ) and DCR $(\mathrm{OR}=4.72,95 \% \mathrm{CI}=1.75-12.72 ; \mathrm{I} 2=56 \%, \mathrm{P}=0.002$; Figure $2 \mathrm{~B}$ ) suggested that patients who underwent the combination therapy tended to have better responses than those who underwent TACE treatment alone.

Significant heterogeneity in DCR was observed. Therefore, the effects were pooled using a random-effects model for between-study variability.

\section{Overall survival}

The median OS was reported in seven of eight retrospective studies [7, 10, 20, 21, 23-25] (Table 4). Moreover, some data were calculated using survival curves. The median OS ranged from 7 to 13 months in the combination treatment group and 4 to 6.1 months in TACE-alone group. Six-month OS and 1-year OS were reported in six of eight retrospective studies [7, 20-24]. In the combination groups, 6-month OS ranged from $67.88 \%$ to $87.7 \%$, and 1 -year OS ranged from $23.9 \%$ to $65.1 \%$. Moreover, 6-month OS ranged from $21.7 \%$ to $63.6 \%$, and 1 -year OS ranged from $0 \%$ to $36.8 \%$ in the TACE-alone treatment group [20-23].

Four studies [7, 20-23] with contrasting results were used to perform meta-analyses of 6-month OS, 1-year OS and HR for OS. Six-month OS in all available studies favored the combination group $(\mathrm{OR}=3.47 ; 95 \% \mathrm{CI}=2.47$ $4.89 ; \mathrm{I}^{2}=0 \%, \mathrm{P}<0.00001$; Figure $3 \mathrm{~A}$ ), as did 1-year OS $\left(\mathrm{OR}=3.10 ; 95 \% \mathrm{CI}=2.22-4.33 ; \mathrm{I}^{2}=41 \%, \mathrm{P}<0.00001\right.$; Figure 3B). Due to this article written by Luo LZ and Luo $\mathrm{D}^{22}$ not providing the specific $\mathrm{HR}, 95 \% \mathrm{CI}$ and survival curves, the study was excluded in a meta-analysis of HR. Similarly, meta-analysis of HR for OS suggested that the patients in the combination therapy group had significantly longer survival than those in the TACE therapy group $(\mathrm{HR}=0.62$; $95 \% \mathrm{CI}=0.51-0.75 ; \mathrm{I}^{2}=30 \%, \mathrm{P}<0.00001$; Figure $3 \mathrm{C}$ ). The meta-analysis showed that OS was significantly greater in the TACE-S group than in the TACE-alone group.

\section{Time to progression}

Five of eight retrospective cohort studies [10, 21, 23-25] reported the median TTP. The median TTP in the combination group ranged from 3 to 7 months in five studies $[10,21,23-25]$. The median TTP in the TACEalone group was 2.4 and 3.0 months in two studies [21, 23]. Chen et al. [21] reported a median TTP of 6.2 months in the combination group versus 2.4 months in the TACEalone group. Similarly, Zhu et al. [23] reported a median TTP of 6.0 months for TACE-S versus 3.0 months for TACE alone. The results suggested that combination therapy group had more time to progression than the TACE-alone group. Two studies [21, 23] compared different effects between TACE-S and TACE alone. Therefore, we did not conduct a meta-analysis (Table 4).

\section{Outcomes of patients with different types of PVTT}

The 8 retrospective studies (Table 2) included a total of 1091 patients with HCC and PVTT, with 356 receiving TACE-S therapy. Some studies [22, 23, 25] analyzed outcomes using the Kaplan-Meier method according to the type of PVTT (PVTT in the main portal vein [type A], PVTT in the first-order portal vein branch [type B], and PVTT in the second- or lower-order portal vein branches [type C]), whereas other studies [20,24] defined PVTT or PVTT type using the Cheng's classification (Type I: tumor thrombus involving segmental branches of the portal vein or above; Type II: tumor thrombus involving the right/ left portal vein; Type III: tumor thrombus involving the main portal vein trunk; Type IV: tumor thrombus involving the superior mesenteric vein) [26]. Compared with two classifications, type A was same to Type III; type B was similar to Type II; and type C was analogous to Type I. This article unified used Cheng's classification. In included studies, Type II was common in all different type of PVTT. All data indicated that patients undergoing combination therapy whose PVTT was in the first-order 
A

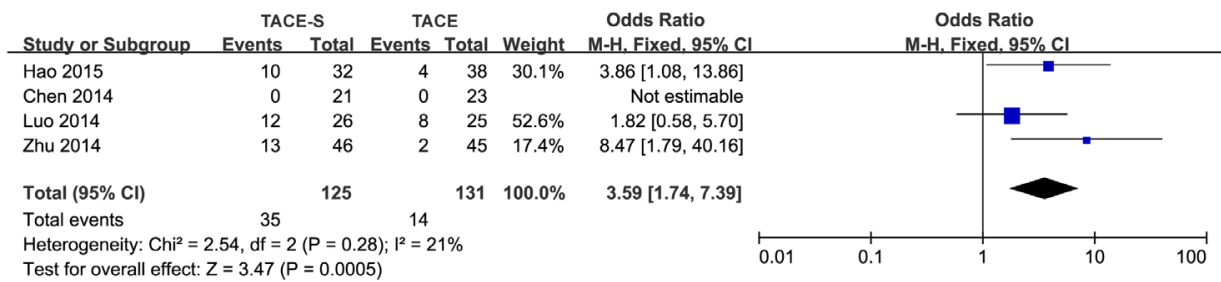

B

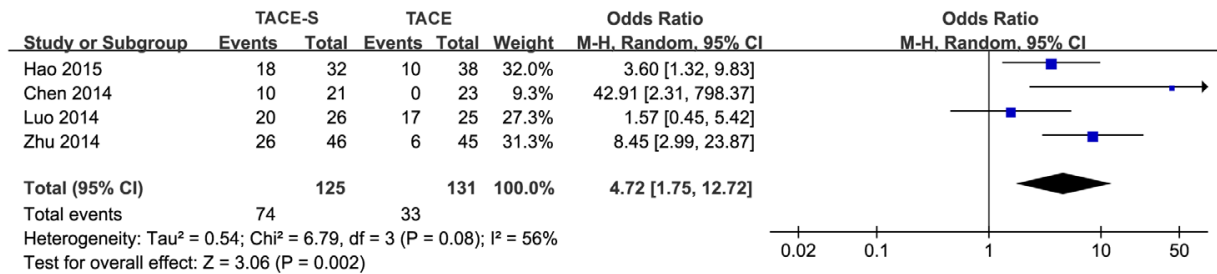

Figure 2: Forest plots for the comparison of tumor response in HCC patients with PVTT who received TACE-S or TACE alone. Outcomes: A. ORR; B. DCR. The meta-analysis of ORR was performed using a fixed-effects model. The meta-analysis of DCR was performed using a random-effects model for significant heterogeneity.

A

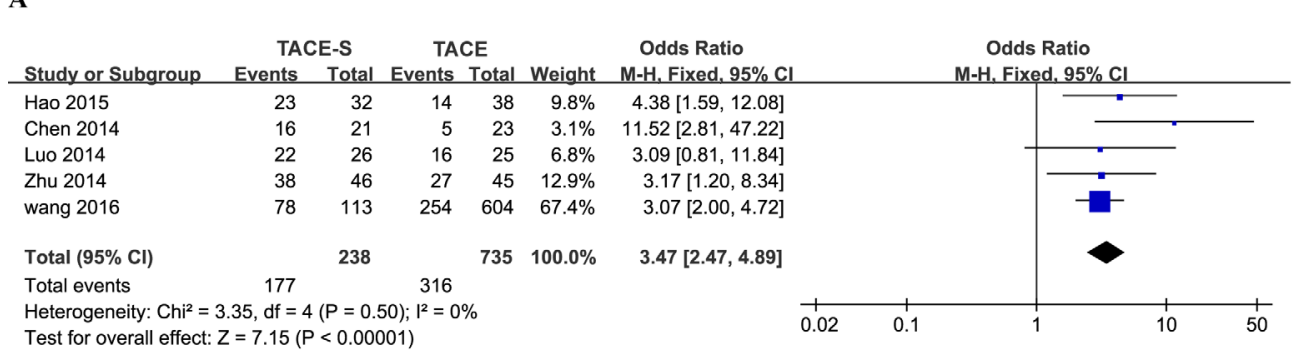

B

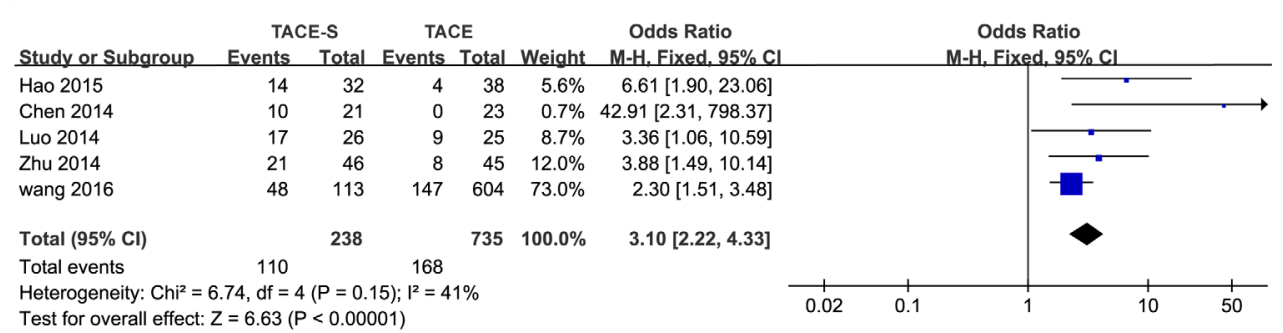

C

\begin{tabular}{|c|c|c|c|c|c|c|c|c|c|}
\hline Study or Subgroup & log[Hazard Ratio] SE & $\begin{array}{l}\text { TACE-S } \\
\text { Total }\end{array}$ & $\begin{array}{l}\text { TACE } \\
\text { Total }\end{array}$ & Weight & $\begin{array}{l}\text { Hazard Ratio } \\
\text { IV. Fixed, } 95 \% \text { Cl Year }\end{array}$ & \multicolumn{4}{|c|}{$\begin{array}{l}\text { Hazard Ratio } \\
\text { IV. Fixed, } 95 \% \text { CI }\end{array}$} \\
\hline Zhu 2014 & $\begin{array}{lll}-0.77 & 0.28\end{array}$ & 46 & 45 & $13.2 \%$ & $0.46[0.27,0.80] 2014$ & & $=$ & & \\
\hline Chen 2014 & $-1.08 \quad 0.44$ & 21 & 23 & $5.3 \%$ & $0.34[0.14,0.80] 2014$ & & & & \\
\hline Hao 2015 & $\begin{array}{ll}-0.68 & 0.33\end{array}$ & 32 & 38 & $9.5 \%$ & $0.51[0.27,0.97] 2015$ & & & & \\
\hline wang 2016 & $\begin{array}{ll}-0.36 & 0.12\end{array}$ & 113 & 604 & $71.9 \%$ & $0.70[0.55,0.88] 2016$ & & & & \\
\hline Total $(95 \% \mathrm{Cl})$ & & 212 & 710 & $100.0 \%$ & $0.62[0.51,0.75]$ & & & & \\
\hline $\begin{array}{l}\text { Heterogeneity: } \mathrm{Ch}^{2}= \\
\text { Test for overall effect }\end{array}$ & $\begin{array}{l}4.30, d f=3(P=0.23) ; I^{2}=30 \% \\
Z=4.75(P<0.00001)\end{array}$ & & & & & 0.2 & 0.5 & 1 & 2 \\
\hline
\end{tabular}

Figure 3: Forest plots for the comparison of odds ratios for overall survival in HCC patients with PVTT who received TACE-S or TACE alone. Outcomes: A. 6-month overall survival; B. 1-year overall survival; C. the hazard ratio for overall survival. A fixed-effects model was used in the meta-analyses of the three outcomes. 
Table 4: The outcomes of therapy for HCC with PVTT.

\begin{tabular}{|c|c|c|c|c|c|}
\hline Study (year) & Treatment & Patients & Median TTP (months) & Median OS(months) & Survival rate (\%) \\
\hline \multirow[t]{2}{*}{ Наo 2015} & $\mathrm{~T}+\mathrm{S}$ & 32 & NA & 10.2 & $\begin{array}{c}71.9(6 \text { months }) \\
43.8 \text { (1year) }\end{array}$ \\
\hline & $\mathrm{T}$ & 38 & NA & 6.0 & $\begin{array}{c}\text { 36.8(6months) } \\
10.5 \text { (1year) }\end{array}$ \\
\hline \multirow[t]{2}{*}{ Chen 2014} & $\mathrm{~T}+\mathrm{S}$ & 21 & $6.2 \pm 0.5$ & $8.4 \pm 1.1$ & $\begin{array}{l}\text { 76.2(6months) } \\
23.9 \text { (1year) }\end{array}$ \\
\hline & $\mathrm{T}$ & 23 & $2.4 \pm 0.3$ & $4.1 \pm 0.6$ & $\begin{array}{c}21.7 \text { (6months) } \\
0 \text { (1year) }\end{array}$ \\
\hline \multirow[t]{2}{*}{ Luo 2014} & $\mathrm{~T}+\mathrm{S}$ & 26 & NA & NA & $\begin{array}{c}\text { 83.0(6months) } \\
65.1 \text { (1year) }\end{array}$ \\
\hline & $\mathrm{T}$ & 25 & NA & NA & $\begin{array}{c}63.6(6 \text { months }) \\
36.8 \text { (1year) }\end{array}$ \\
\hline \multirow[t]{2}{*}{ Zhu 2014} & $\mathrm{~T}+\mathrm{S}$ & 46 & 6.0 (95\%CI:4.9-7.1) & 11.0 (95\%CI:7.8-14.2) & $\begin{array}{c}82.6(6 \text { months }) \\
45.7 \text { (1year) }\end{array}$ \\
\hline & $\mathrm{T}$ & 45 & 3.0 (95\% CI: 2.2-3.8) & 6.0 (95\% CI:4.9-7.1) & $\begin{array}{c}60.0 \text { (6months) } \\
17.8 \text { (1year) }\end{array}$ \\
\hline Zhang 2015 & $\mathrm{~T}+\mathrm{S}$ & 45 & 3.0 & 7.0 & NA \\
\hline Pan 2014 & $\mathrm{~T}+\mathrm{S}$ & 41 & 7 & 13.0 & $\begin{array}{c}87.7 \text { (6months) } \\
53.6 \text { (1year) }\end{array}$ \\
\hline Chen JW 2013 & $\mathrm{~T}+\mathrm{S}$ & 32 & 3 & 7 & NA \\
\hline \multirow[t]{2}{*}{ Wang 2016} & $\mathrm{~T}+\mathrm{S}$ & 113 & NA & 8.92(95\%CI:7.86-10.97) & $\begin{array}{c}67.88 \text { (6months) } \\
37.36 \text { (1year) }\end{array}$ \\
\hline & $\mathrm{T}$ & 604 & NA & 4.79(95\%CI:4.07-5.45) & $\begin{array}{c}41.56 \text { (6months) } \\
24.16 \text { (1year) }\end{array}$ \\
\hline
\end{tabular}

Table 5: The outcomes of patients with TACE plus sorafenib combination therapy for various PVTT types.

\begin{tabular}{|c|c|c|c|c|c|c|}
\hline Study (year) & Treatment & Type of PVTT & Patients & Median TTP(months) & Median OS(months) & DCR (\%) \\
\hline \multirow[t]{8}{*}{ Hao 2015} & $\mathrm{~T}+\mathrm{S}$ & Type I & 8 & NA & 19.8 & NA \\
\hline & & Type II & 14 & NA & 10.3 & $\mathrm{NA}$ \\
\hline & & Type III & 7 & NA & 8.1 & $\mathrm{NA}$ \\
\hline & & Type IV & 3 & NA & 2.1 & $\mathrm{NA}$ \\
\hline & $\mathrm{T}$ & Type I & 6 & NA & 10.2 & NA \\
\hline & & Type II & 21 & NA & 6.0 & $\overline{\mathrm{NA}}$ \\
\hline & & Type III & 7 & NA & 3.0 & $\mathrm{NA}$ \\
\hline & & Type IV & 4 & NA & 2.0 & NA \\
\hline Chen 2014 & NA & NA & $\mathrm{NA}$ & NA & $\mathrm{NA}$ & $\mathrm{NA}$ \\
\hline \multirow[t]{6}{*}{ Luo 2014} & $\mathrm{~T}+\mathrm{S}$ & Type III & NA & NA & 3 & NA \\
\hline & $\mathrm{T}+\mathrm{S}$ & Type II & $\mathrm{NA}$ & NA & 12 & NA \\
\hline & $\mathrm{T}+\mathrm{S}$ & Type I & NA & NA & 14 & NA \\
\hline & $\mathrm{T}$ & Type III & NA & NA & 2.8 & $\overline{\mathrm{NA}}$ \\
\hline & $\mathrm{T}$ & Type II & NA & NA & 7 & $\overline{\mathrm{NA}}$ \\
\hline & $\mathrm{T}$ & Type I & NA & NA & 11 & $\overline{\mathrm{NA}}$ \\
\hline \multirow[t]{6}{*}{ Zhu 2014} & $\mathrm{~T}+\mathrm{S}$ & Type III & 10 & 0 & 3 & 10 \\
\hline & $\mathrm{T}+\mathrm{S}$ & Type II & 19 & 6 & 13 & 58 \\
\hline & $\mathrm{T}+\mathrm{S}$ & Type I & 17 & 7 & 15 & 82 \\
\hline & $\mathrm{T}$ & Type III & 10 & 0 & 3 & 0 \\
\hline & $\mathrm{T}$ & Type II & 21 & 3 & 6 & 14 \\
\hline & $\mathrm{T}$ & Type I & 13 & 5 & 10 & 23 \\
\hline Zhang 2015 & NA & NA & NA & NA & NA & NA \\
\hline \multirow[t]{2}{*}{ Pan 2014} & $\mathrm{~T}+\mathrm{S}$ & Type II- III & 31 & NA & 14.0 & NA \\
\hline & & Type IV & 10 & NA & 7.8 & NA \\
\hline \multirow[t]{3}{*}{ ChenJW2013 } & $\mathrm{T}+\mathrm{S}$ & Type III & 10 & 0 & 3 & 20.0 \\
\hline & $\mathrm{T}+\mathrm{S}$ & Type II & 10 & 3 & 9 & 70.0 \\
\hline & $\mathrm{T}+\mathrm{S}$ & Type I & 12 & 6 & 14 & 91.7 \\
\hline \multirow[t]{6}{*}{ Wang 2016} & $\mathrm{~T}+\mathrm{S}$ & Type I & 31 & NA & 12.01 & NA \\
\hline & $\mathrm{T}+\mathrm{S}$ & Type II & 45 & NA & 8.92 & NA \\
\hline & $\mathrm{T}+\mathrm{S}$ & Type III & 37 & NA & 6.96 & NA \\
\hline & $\mathrm{T}$ & Type I & 47 & NA & 9.28 & NA \\
\hline & $\mathrm{T}$ & Type II & 288 & NA & 4.97 & NA \\
\hline & $\mathrm{T}$ & Type III & 269 & NA & 3.98 & NA \\
\hline
\end{tabular}


Table 6: Adverse events

\begin{tabular}{|c|c|c|c|c|c|c|c|c|c|c|}
\hline Study & $\begin{array}{l}\text { HFSR } \\
(n / \%)\end{array}$ & $\begin{array}{l}\text { Hemorrhage of } \\
\text { digestive tract } \\
(n / \%)\end{array}$ & $\begin{array}{l}\text { Diarrhea } \\
(n / \%)\end{array}$ & $\begin{array}{l}\text { Hypertension } \\
(\boldsymbol{n} / \%)\end{array}$ & $\begin{array}{l}\text { Oral } \\
\text { ulcer } \\
(n / \%)\end{array}$ & $\begin{array}{l}\text { Fatigue } \\
(n / \%)\end{array}$ & $\begin{array}{l}\text { Alopecia } \\
(n / \%)\end{array}$ & $\begin{array}{l}\text { Liver } \\
\text { dysfunction } \\
(n / \%)\end{array}$ & $\begin{array}{l}\text { Rash/ } \\
\text { Desquamation } \\
(n / \%)\end{array}$ & \begin{tabular}{|l} 
grade $3 / 4$ \\
adverse \\
eventsa
\end{tabular} \\
\hline Наo 2015 & $23(71.8)$ & $1(3.1)$ & $22(68.8)$ & $3(9.4)$ & $1(3.1)$ & NA & $12(37.5)$ & NA & $\mathrm{NA}$ & 4 \\
\hline Chen 2014 & $19(90.5)$ & $4(19)$ & $14(66.7)$ & $2(9.5)$ & $2(9.5)$ & NA & NA & NA & NA & NA \\
\hline Luo 2014 & 19(73.08) & NA & $6(23.08)$ & $2(7.7)$ & $9(34.61)$ & NA & $4(15.38)$ & $10(38.36)$ & NA & NA \\
\hline Zhu 2014 & $37(80)$ & $4(9)$ & $33(72)$ & $6(13)$ & $\mathrm{NA}$ & $13(28)$ & $15(33)$ & $2(4)$ & $\mathrm{NA}$ & 16 \\
\hline Zhang 2015 & $29(64.4)$ & $3(6.6)$ & $20(44.4)$ & $1(2.2)$ & $\mathrm{NA}$ & $11(24.4)$ & 25 (55.6) & $25(55.6)$ & $\mathrm{NA}$ & 16 \\
\hline Pan 2014 & $28(68.3)$ & NA & $22(53.7)$ & $4(9.8)$ & $\mathrm{NA}$ & $9(22)$ & $8(19.5)$ & NA & $9(22)$ & 4 \\
\hline $\begin{array}{ll}\text { Chen } & \text { JW } \\
2013 & \end{array}$ & $23(71.9)$ & $2(6.2)$ & $25(78.1)$ & $3(9.4)$ & $1(3.1)$ & NA & $12(37.5)$ & NA & NA & 6 \\
\hline Wang 2016 & NA & NA & NA & NA & NA & NA & NA & NA & NA & NA \\
\hline total & $178(73)$ & $14(6)$ & $142(58)$ & 21(9) & $13(5)$ & $33(14)$ & $76(31)$ & $37(15)$ & $9(4)$ & NA \\
\hline
\end{tabular}

portal vein branch or lower-order portal vein branches, Type I-II, had better results than those whose PVTT was in the main portal vein or the upper branches to superior mesenteric vein, Type III-IV. (Table 5).

\section{Adverse events}

AEs were reported in all included studies and included HFSR, hemorrhage of the digestive tract, diarrhea, hypertension, fatigue, alopecia, liver dysfunction, oral ulcer, and rash/desquamation. AEs experienced during combination therapy are shown in Table 6. A total of 243 patients received combination therapy. The most common AEs were HFSR (178; 73\%), diarrhea (142; 58\%) and alopecia $(76 ; 31 \%)$. AEs of grade $3 / 4$ were rare. The studies by Chen et al. [21] and Luo LD and Luo Z [22] indicated that sorafenib increased the probability of HFSR and diarrhea. More AEs were associated with sorafenib in the combination groups.

There was no obvious difference in AEs related to TACE between the combination therapy group and the TACE-alone group. Sorafenib did not increase the probability of AEs related to TACE. Therefore, we will not discuss differences in AEs in detail.

\section{DISCUSSION}

Comprehensive treatments are available for HCC patients with PVTT, but high disease recurrence limits the effectiveness of these treatments. Although several studies have shown that TACE is effective in the treatment of patients with PVTT alone and the effect of TACE on improving the 1-year survival rates of patients with HCC and PVTT [27,28], few have evaluated the results of TACE combined with other treatments applied in patients with PVTT. This study is the first systematic review and meta-analysis to aim to identify nearly all studies of documents about TACE-S for the treatment of
PVTT, analyze the curative effects and the safety of this combined therapy and provide a foundation for the clinical treatment of PVTT.

In summary, the combined therapy was more effective than TACE alone. Tumor response is an important aspect of short-term curative effects. TACE-S was associated with higher ORR and DCR for patients with PVTT. With respect to the long-term curative effect, OS should be discussed, such as the median TTP, median OS and survival rate. This study revealed that combination therapy improved the 6-month and 1-year OS of HCC patients with PVTT.

Several mechanisms may underlie the complementary roles of TACE and sorafenib. Embolization of the hepatic artery by TACE reduces the blood supply of HCC, achieving the goal of treatment. However, the side effects of TACE include increased vascular endothelial growth factor (VEGF) expression, liver function damage and increased possibility of the recurrence of HCC [29]. Sorafenib is a small-molecule multikinase inhibitor with antiangiogenic properties that primarily acts through the vascular endothelial growth factor 2 (VEGFR-2) pathway, platelet-derived growth factor receptor (PDGFR) pathway and Raf signaling pathway. Sorafenib can block neoangiogenesis and HCC growth [30], significantly improving OS and TTP in patients with advanced HCC [31]. Thus, sorafenib can reduce the side effects of TACE and improve the positive effects of TACE compared to TACE alone. Recent one study has revealed collaborative efficiency of TACE using oxaliplatin and doxorubicin with sorafenib, particularly in blocking HCC growth and neoangiogenesis as well as improving OS [32]. Our systematic review included 8 trials, all of which revealed the same effect in patients with PVTT. However, only one meta-analysis [12] showed that TACE-S might be superior to TACE alone in terms of TTP but not OS in advanced HCC patients without PVTT, perhaps because these patients had no PVTT, although this finding is worth exploring further. 
Regarding safety, serious AEs were rare in the 243 included patients receiving combination therapy. Only 40 patients who had serious AEs were cured. The most common AEs were HFSR and diarrhea related to sorafenib. During combination therapy, sorafenib did not increase the risks of TACE treatment [33]. Moreover, patients who had light symptoms were able to treat their discomfort, whereas patients with severe symptoms reduced the dose of sorafenib or paused their sorafenib treatment and used affordable, relevant auxiliary treatments to relieve and reverse AEs [34]. However, these methods also hamper the benefits of TACE-S. Our results were similar to those of previous meta-analyses of patients without PVTT [1214]. Thus, the combination therapy has better tolerance and safety, and severe AEs were controllable.

Patients' liver function and the extent of PVTT in the portal vein could determine the selection of treatments [7]. We must pay attention to the patients' liver function and select appropriate treatments to reduce AEs. According to the study of Wang, et al. [7], surgery and TACE+RT may improve the overall survivals of HCC patients with PVTT. Surgery was the best treatment for type I and II PVTT patients with Child-Pugh A and selected B liver function. TACE-RT should be given to type III PVTT patients. Further, A Chinese expert consensus on multidisciplinary diagnosis and treatment of hepatocellular carcinoma with portal vein tumor thrombus (2016 edition) [35] led in our hospital has published online recently, the first expert consensus aiming to PVTT in the world, which could guide to treat these patients. Our studies concentrated on the comparison of TACE-S and TACE for PVTT. TACE-S may also improve OS of PVTT patients who could not be performed surgery and RT. This systematic review and meta-analysis may improve the level of evidences in Chinese expert consensus and provide references for PVTT patients in other countries. Finally, no RCTs were available and lack of prospective nature of studies included significantly increase the bias, and the results require confirmation in further high-quality trials.

There are several limitations of this analysis that should be considered when interpreting the findings. Although the 8 retrospective studies included in the systematic review and the 5 studies included in the meta-analysis scored 7-8, the use of different treatment options in the different studies might have influenced the reliability of the conclusions. Firstly, publication bias existed in our studies with natural quality. However, because of the limited number of included studies and hence limited statistical power, publication bias test was not performed in our article according to Begg's and Egger's recommendation [19]. Secondly, all of the included studies were conducted in China. We have systematically searched databases based on our search strategy, and all relevant studies were included to our analysis. In China, HCC is the one of the highest cancer killer and HBV infection is highly endemic. In diagnosis and treatment for PVTT, clinicians and researchers had rich experience. Thus, all the included studies designed in China have great reliability.

In conclusion, this systematic review and metaanalysis suggests that TACE-S is superior to TACE alone. It is imperative to design additional rigorous, multicenter RCTs with large samples to assess the long-term curative effects and improve the stability of TACE-S for PVTT.

\section{MATERIALS AND METHODS}

\section{Search strategy}

We systematically searched the Cochrane Library, PubMed, EMBASE, Chinese National Knowledge Infrastructure (CNKI), VIP, Wan Fang, and Sino Med databases, with no limitations on language and with a limitation to human studies to obtain useful data; similarly, we searched ClinicalTrials.gov to obtain available outcomes of ongoing studies. The following search strategies were used: "transcatheter arterial chemoembolization" or "TA (C)E" or "transarterial chemoembolization" or "chemoemboli*" or "emboli*" AND "sorafenib" or "Nexavar" or "Raf 1 Kinase Inhibitor II" AND "portal vein tumor thrombus" or "(portal vein thrombosis)" or "PVTT" AND "(liver or hepatic or hepatocellular or hepatocellular) and (carcinom* OR cancer OR neoplasm* OR malign* OR tumor* OR tumour*)" or "HCC" or "hepatoma*". All abstracts were screened independently by Zhang X P and Wang M, and full-text reports of suitable papers were obtained for another screen. We also searched the relevant references of the retrieved papers.

\section{Study selection}

Inclusion Criteria

1. HCC patients with various PVTTs.

2. Clinical trials using sorafenib plus TACE or comparing TACE-S with TACE therapy alone for the treatment of HCC patients with PVTT.

3. Trials including the following: overall survival (OS), time to progression (TTP), tumor response, and related information about the original data and that could be calculated.

4. Relevant conference summaries and degree papers about sorafenib plus TACE for PVTT, with no publication language limitation applied.

Exclusion Criteria

1. HCC patients without PVTT and patients receiving methods of treatment other than TACE and sorafenib. 
2. Case reports, current affairs review, reviews and other meta-analyses and studies that did not provide all necessary information to evaluate the quality of the study.

3. For repeated publications, repetition, or information from the same study, only the latest study was used, and the others were excluded.

\section{Data extraction and quality assessment}

All data from the trial reports were extracted and checked independently by two reviewers (Zhang XP and Wang M). If necessary, a third author (Wang K) was invited to participate in the resolution differences. Meanwhile, the reasons for excluding studies were documented.

1. The extracted basic data included the authors, year of publication, country, study design, sex of patients, number of patients, median daily dosage of sorafenib, and median number of TACE sessions.

2. Data about the state of HCC were collected, such as HCC stage (ECOG), size and characteristics of HCC (AFP), liver function (Child A/B/C), and types of PVTT.

3. Finally, some data were included about the experimental content, such as the study methods and outcomes (OS, 6month, 1 year), TTP, DCR (disease control rate), and incidence of adverse events (diarrhea, hand-foot skin reactions (HFSR), hypertension).

All data were included in the TACE alone and TACE-S groups. Three of the authors (Zhang XP, Wang $M$ and Wang K) independently extracted the data and then entered the requisite data into RevMan software, version 5.3 (The Cochrane Collaboration. http://tech.cochrane. org, Updated June 2014). For nonrandomized, controlled trials (NRCTs), the quality of observational studies was assessed using the Newcastle-Ottawa Scale (NOS)[16] to appraise the risk of bias in the selection of study groups and comparability of groups.

\section{Statistical analysis}

The study outcomes included OS, TTP, treatment response (CR, PR, and SD) and AEs. Tumor response (CR, PR, and SD) was evaluated using the Response Evaluation Criteria in Solid Tumors (RECIST) criteria or the modified RECIST criteria [17]. Adverse events were categorized using the National Cancer Institute criteria: PDQ $^{\circledR}$ Cancer Genetics Risk Assessment and Counseling. (http://cancer.gov/cancertopics/pdq/genetics/ risk-assessment-and-counseling/HealthProfessional.) and National Comprehensive Cancer Network (NCCN): The NCCN Clinical Practice Guidelines in Oncology TM 2010. (www.nccn.com.). The main outcome measurements were summarized using descriptive statistics. The comparative outcomes were pooled by meta-analysis using RevMan version 5.3.

The results are presented as hazard ratios (HRs) and odds ratio (ORs) with 95\% confidence intervals (CIs) for all outcomes to evaluate OS, TTP and tumor response. Some OS data were obtained from survival curves. The natural logarithm of the HR and its standard error (SE) were calculated using the relevant statistical methods and calculation sheets prepared by Matthew Sydes and Jayne Tierney, as reported previously [18]. The survival rates at different time points based on the survival curves were entered into the calculation sheet "(2a) curve data". Accordingly, a curve was produced in the calculation sheet "( $2 \mathrm{~b})$ curve copy", and $\ln [\mathrm{HR}]$ and se $(\ln [\mathrm{HR}])$ were available in the calculation sheet "(4) output information". Patients who underwent at least one round of TACE-S therapy were included in the safety analysis.

Q statistics and $\mathrm{I}^{2}$-index, according to the suggestions of the Cochrane collaboration, were used to assess the heterogeneity of the included studies. $\mathrm{P}<$ 0.05 with an $\mathrm{I}^{2}$-index $>50 \%$ was considered to indicate significant heterogeneity. The estimates were pooled with a fixed-effect model if no significant heterogeneity was identified. Otherwise, the effects were pooled with a random-effects model that accounted for both within- and between-study variability.

\section{Quality of evidence and risk of bias}

The quality of non-randomized studies was assessed by the NOS, which included the evaluation of risk of bias in the selection of study groups, comparability of groups, and ascertainment of the exposure or outcome of interest. Although 2 to 3 articles have published in Chinese journals, these journals, acknowledged by the peers, have a high credibility in HCC field in China. The scores ranged from 7 to 8 , indicating that these studies had high quality.

Publication bias was not evaluated in any of the outcomes because the number of studies reported was less than five; thus assessing for publication bias using funnel plots, Begg's test and Egger's test was inappropriate [19].

In all sensitivity analyses, there was no significant heterogeneity or deviation among the included studies. Sensitivity analysis was performed using the leaveone-out approach in the meta-analysis, using RevMan software, version 5.3. The direction and magnitude of pooled estimates did not change when removing studies, indicating that the all meta-analyses had good reliability and were not overly influenced by one of the included studies.

\section{ACKNOWLEDGMENTS}

This work was supported by grants from the National Key Basic Research Program "973 project" 
(No: 2015CB554000), the Science Fund for Creative Research Groups (No:81521091); the China National Funds for Distinguished Young Scientists (No: 81125018); the ChangJiang Scholars Program (2013) of the Chinese Ministry of Education; the Shanghai Science and Technology Committee (No: 134119a0200, SHDC12015106); the National Natural Science Foundation of China, No: 8160110271, and the SMMU Innovation Alliance for Liver Cancer Diagnosis and Treatment (2012).

\section{CONFLICTS OF INTEREST}

There are no financial disclosures, conflicts of interest, and/or acknowledgements.

\section{REFERENCES}

1. Forner A, Llovet JM, Bruix J. Hepatocellular carcinoma. Lancet. 2012; 379: 1245-1255.

2. Faloppi L, Scartozzi M, Maccaroni E, Di Pietro Paolo M, Berardi R, Del Prete M, Cascinu S. Evolving strategies for the treatment of hepatocellular carcinoma: fromclinicalguided to molecularly-tailored therapeutic options. Cancer Treat Rev. 2011; 37: 169-177.

3. Zhang ZM, Lai EC, Zhang C, Yu HW, Liu Z, Wan BJ, Liu LM, Tian ZH, Deng H, Sun QH, Chen XP. The strategies for treating primary hepatocellular carcinoma with portal vein tumor thrombus. Int J Surg. 2015; 20: 8-16.

4. Yang T, Lin C, Zhai J, Shi S, Zhu M, Zhu N, Lu JH, Yang GS, Wu MC. Surgical resection for advanced hepatocellular carcinoma according to Barcelona Clinic Liver Cancer (BCLC) staging. J Cancer Res Clin Oncol. 2012; 138: 11211129.

5. Chung GE, Lee JH, Kim HY, Hwang SY, Kim JS, Chung JW, Yoon JH, Lee HS, Kim YJ. Transarterial chemoembolization can be safely performed in patients with hepatocellular carcinoma invading the main portal vein and may improve the overall survival. Radiology. 2011; 258: 627-634.

6. Leng J, Xu Y, Dong J. Efficacy of transarterial chemoembolization for hepatocellular carcinoma with portal vein thrombosis: a meta-analysis. ANZ J Surg. 2014; doi 10.1111/ans.12803.

7. Wang K, Guo WX, Chen MS, Mao YL, Sun BC, Shi J, Zhang YJ, Meng Y, Yang YF, Cong WM, Wu MC, Lau WY, Cheng SQ. Multimodality treatment for hepatocellular carcinoma with portal vein tumor thrombus: a large-scale, multicenter, propensity mathching score analysis. Medicine. 2016; 95: e3015.

8. Kim JH, Yoon HK, Kim SY, Kim KM, Ko GY, Gwon DI, Sung KB. Transcatheter arterial chemoembolization vs. chemoinfusion forunresectable hepatocellular carcinoma in patients with majorportal vein thrombosis. Aliment Pharmacol Ther. 2009; 29: 1291-1298.
9. Li Q, Wang J, Sun Y Cui YL, Juzi JT, Li HX, Qian BY, Hao XS. Efficacy of postoperative transarterial chemoembolization and portal vein chemotherapy for patients with hepatocellular carcinoma complicated by portal vein tumor thrombosis - a randomized study. World J Surg. 2006; 30: 2004-2011.

10. Zhang Y, Fan W, Wang Y, Lu L, Fu S, Yang J, Huang Y, Yao W, Li J. Sorafenib with and without transarterial chemoembolization for advanced hepatocellular carcinoma with main portal vein tumor thrombosis: a retrospective analysis. Oncologist. 2015; 20: 1417-1424.

11. Chen J, Zhu K, Meng X, Huang W. Transarterial chemoembolization combined with sorafenib for advanced hepatocellular carcinoma with portal vein tumor thrombus: a prospective control study. J Vasc Interv Radiol. 2013; 24: S65-S66.

12. Fu QH, Zhang Q, Bai XL, Hu QD, Su W, Chen YW, Su $\mathrm{RG}$, Liang TB. Sorafenib enhances effects of transarterial chemoembolization for hepatocellular carcinoma: a systematic review and meta-analysis. J Cancer Res Clin Oncol. 2014; 140: 1429-1440.

13. Yang M, Yuan JQ, Bai M, Han GH. Transarterial chemoembolization combined with sorafenib for unresectable hepatocellular carcinoma: a systematic review and meta-analysis. Mol Biol Rep. 2014; 41: 6575-6582.

14. Liu L, Chen H, Wang M, Zhao Y, Cai G, Qi X, Han G. Combination therapy of sorafenib and TACE for unresectable HCC: a systematic review and meta-analysis. PLOS ONE. 2014; 9: e91124.

15. Abdel-Rahman O, Elsayed ZA. Combination trans arterial chemoembolization (TACE) plus sorafenib for the management of unresectable hepatocellular carcinoma: a systematic review of the literature. Dig Dis Sci. 2013; 58: 3389-3396.

16. Wells GA, Shea B, O'Connell D, Peterson J, Welch V, Losos M,Tugwell P. Newcastle-Ottawa Scale (NOS) for assessing the quality of nonrandomised studies in metaanalyses. The Ottawa Hospital: Research Institute. 2009. Available from URL: http://www.ohri.ca/programs/ clinical_epidemiology/oxford.asp

17. Watanabe H, Okada M, Kaji Y, Satouchi M, Sato Y, Yamabe Y, Onaya H, Endo M, Sone M, Arai Y. [New response evaluation criteria in solid tumours-revised RECIST guideline (version 1.1)]. Gan To Kagaku Ryoho. 2009; 36: 2495-2501.

18. Tierney JF, Stewart LA, Ghersi D, Burdett S, Sydes MR. Practical methods for incorporating summary time-to-event data into meta-analysis. Trials. 2007; 8: 16.

19. Sutton AJ, Duval SJ, Tweedie RL, Abrams KR, Jones DR. Empirical assessment of effect of publication bias on metaanalyses. BMJ. 2000; 320: 1574-1577.

20. Hao JL. Hepatic arterial chemoembolization in combination with sorafenib for primary liver cancer with portal vein tumor thrombus. Master's thesis. Nanning, China: Guangxi 
Medical University. 2015; R735: 7. (in Chinese)

21. Chen J, Xi W, Wu B, Yu H, Chen S. Clinical observation of transcatheter arterial chemoembolization plus sorafenib in the treatment of hepatocellular carcinoma with portal vein tumor thrombosis. Zhong hua Yi Xue Za Zhi. 2014; 94: 2566-2569.

22. Luo LD, Luo Z. Efficacy and safety analysis of sorafenib combined with transcatheter arterial chemoembolization in the treatment of hepatocellular carcinoma with portal vein tumor thrombus. Journal Chinese Physician. 2014; 16 : 1699-1701.(in Chinese)

23. Zhu K, Chen J, Lai L, Meng X, Zhou B, Huang W, Cai $\mathrm{M}$ and Shan H. Hepatocellular carcinoma with portal vein tumor thrombus: treatment with transarterial chemoembolization combined with sorafenib--a retrospective controlled study. Radiology. 2014; 272: 284 293.

24. Pan T, Li XS, Xie QK, Wang JP, Li W, Wu PH, Zhao M. Safety and efficacy of transarterial chemoembolization plus sorafenib for hepatocellular carcinoma with portal venous tumour thrombus. Clin Radiol. 2014; 69: e553-e561.

25. Chen JW, Pang PF, Meng XC, Zhou B, Huang WS, Guo YJ, Zhu KS, Shan H. Clinical observation of transcatheter arterial chemoembolization plus sorafenib in the treatment of advanced hepatocellular carcinoma with different types of portal vein tumor thrombosis. Zhong hua Yi Xue Za Zhi. 2013; 93: 663-667.

26. Shi J, Lai EC, Li N, Guo WX, Xue J, Lau WY, Wu MC, Cheng SQ. A new classification for hepatocellular carcinoma with portal vein tumor thrombus. J Hepato Biliary Pancreat Sci. 2011; 18: 74-80.

27. Leng JJ, Xu YZ, Dong JH. Efficacy of transarterial chemoembolization for hepatocellular carcinoma with portal vein thrombosis: a meta-analysis. ANZ J Surg. 2014; doi 10.1111/ans.12803.

28. Quirk M, Kim YH, Saab S, Lee EW. Management of hepatocellular carcinoma with portal vein thrombosis. World J Gastroenterol. 2015; 21: 3462-3471.

29. Li X, Feng GS, Zheng CS, Zhuo CK, Liu X. Expression of plasma vascular endothelial growth factor in patients with hepatocellular carcinoma and effect of transcatheter arterial chemoembolization therapy on plasma vascular endothelial growth factor level. World J Gastroenterol. 2004; 10: 2878 2882.
30. Chang YS, Adnane J, Trail PA, Levy J, Henderson A, Xue D, Bortolon E, Ichetovkin M, Chen C, McNabola A, Wilkie D, Carter CA, Taylor IC, et al. Sorafenib (BAY 43-9006) inhibits tumor growth and vascularization and induces tumor apoptosis and hypoxia in RCC xenograft models. Cancer Chemother Pharmacol. 2007; 59: 561-574.

31. Llovet JM, Ricci S, Mazzaferro V, Hilgard P, Gane E, Blanc JF, de Oliveira AC, Santoro A, Raoul JL, Forner A, Schwartz M, Porta C, Zeuzem S, et al. Sorafenib in advanced hepatocellular carcinoma. N Engl Jmed. 2008; 359: 378-390.

32. Richly H, Schultheis B, Adamietz IA, Kupsch P, Grubert M, Hilger RA, Ludwig M, Brendel E, Christensen O, Strumberg D. Combination of sorafenib and doxorubicin in patients with advanced hepatocellular carcinoma: results from a phase I extension trial. Eur J Cancer. 2009; 45: 579587.

33. Abou-Alfa GK, Schwartz L, Ricci S, Amadori D, Santoro A, Figer A, De Greve J, Douillard JY, Lathia C, Schwartz B, Taylor I, Moscovici M, Saltz LB. Phase II study of sorafenib in patients with advanced hepatocellular carcinoma. J Clin Oncol. 2006; 24: 4293-4300.

34. Zhao Y, Wang WJ, Guan S, Li HL, Xu RC, Wu JB, Liu JS, Li HP, Bai W, Yin ZX, Fan DM, Zhang ZL, Han GH. Sorafenib combined with transarterial chemoembolization for the treatment of advanced hepatocellularcarcinoma: a large-scale multicenter study of 222 patients. Ann Oncol. 2013; 24: 1786-1792.

35. Cheng S, Chen M, Cai J; National Research Cooperative Group for Diagnosis and Treatment of Hepatocellular Carcinoma. Chinese expert consensus on multidisciplinary diagnosis and treatment of hepatocellular carcinoma with portal vein tumor thrombus: 2016 edition. Oncotarget. 2017; 8:8867-8876. doi: 10.18632/oncotarget.12817. 